\title{
Flooding Causes Analysis in The Engine Room of KM. Nusantara Akbar
}

\author{
Trika Pitana ${ }^{1}$, Hari Prastowo ${ }^{2}$, M. Badrus Zaman ${ }^{3}$, Aleik Nurwahyudi $^{4}$, Rachmat Gunawan $^{5}$
}

\begin{abstract}
KM Nusantara Akbar's engine room. However, this study mainly focuses on flooding that caused by shaft deflection. It was found that the cause of the flooding was packing, driven by a deflection shaft. Analysis was done by a review of the technical and non-technical factors. The analyze of engine room flooding is carried out by using 5 whys method to asses the root causes. The results show that the causes of flooding are reconditioned flange bolts that have been damaged and the addition of flax on the bearing shaft has to cope without straightening axle deflection itself, equipment to overcome the failure system is very less, the workplace is dirty and uncomfortable and happened miss communication between the crews.
\end{abstract}

Keywords — deflection, flooding, shafting system, 5 whys

\section{INTRODUCTION}

$\mathrm{F}$ looding of vessel shall be avoided as much as possible because it may cause harm to the captain and crew, vessel owners, marine environment and disruption of marine ecosystem. Flood in the vessel can occur because the vessel ran aground, fire, vessel plate is corrosion or internal factors such as failure of shafting system. Emergency situation will occurred when the water enters quickly into a compartment of the vessel, but in the other side, the ability to overcome the flooding is limited. More complicated situation will come when the decision-making and implementation is not fully supported by crew.

All components in the engine room will affect to the ship performance, therefore it is very important to keep the condition of components in the engine room. One example of a system in the engine room is shafting system that the function is deliver the trust power from the main engine to the propeller as a driver.

This research will analyze the causes of the flooding of the engine room KM. Nusantara Akbar, which is caused by shaft deflection. It is known that the causes of flood in the engine room is packing driven by shaft deflection, therefore packing cannot withstand the flow of water.

This research is conducted on the two factors, the technical factors and the non-technical factors. Technical factors is a factor based on the workings of the existing system in the engine room, especially the

Trika Pitana, Department of Marine Engineering, Institut Teknologi Sepuluh Nopember, Surabaya 60111, Indonesia, Email trika@its.ac.id

Hari Prastowo, Department of Marine Engineering, Institut Teknologi Sepuluh Nopember, Surabaya 60111, Indonesia, Email : hariprastowo@gmail.com

Muhammad Badrus Zaman, Department of Marine Engineering, Institut Teknologi Sepuluh Nopember, Surabaya 60111, Indonesia, Email :druz_zaman@ne.its.ac.id

Aleix Nurwahyudi, National Transportation Safety Committee, Indonesia, Email: -

Rachmat Gunawan, Department of Marine Engineering, Institut Teknologi Sepuluh Nopember, Surabaya 60111, Indonesia, Email : rachmat.gunawan@ymail.com shaft system and its components, while for the nontechnical factors are the other factors that affect the workings of the systems that exist in the engine room, especially for shafting systems such as crew, workplace conditions and others. first, each of technical and nontechnical factors is performed using the fault tree. This method is a technique to identify all the problems in a given situation and to demonstrate this information as a series of causal relation vessel. Secondly, It is conducted technical factors and non-technical factors by using the 5 whys method. Basically, 5 whys method is the question and answer technique to investigate the root cause of the problems. This technique is the practice of asking why five times to determine the root cause of a defect or problem. Then for the technical factors evaluated by using Finite Elemet Method (FEM) modeling, complying with BKI rules related to shafting systems.

\section{METHOD}

\section{II.1. 5 WHYS}

5 whys method is a method to investigate the causeeffect in trouble or failure events [1]. The 5 whys is a simple way to try to solve the problem without a detailed investigation that requires a lot of resources. When the problem involves human factors, this method is the easiest to use. This method is one of the simplest methods of investigation that can easily be solved without statistical analysis or also known as why tree, where it is the simplest form of analysis of the root cause, by repeatedly asking the question, "Why?" it can peel the layers of problems and symptoms that can lead to the root cause.

In the first step, begins with a statement that is why it happened. The next step is to change the answer from the

first question as why for the second question and so on. With emphasis on the question of why, then it will increase the chances of finding the root cause of the underlying problem or failure. Although this technique is called 'five whys', five is the rule of thumb. In addition there is also the theory that 7 'why' is better and that the 5 'why' is not enough to looking for the real cause of the failure. 
In the 5 whys analysis also implied a method though not often stated openly, that the use of why tree like on Figure 1, this method is also called Fault Tree Analysis. This method is one of the best ways to start the 5 whys method that causes that may be visible. Why tree which was originally just a simple matter to grow up with a variety of causal branches.
This method use tables to register successive questions and answers. Table 1 is an example of the method 5 whys. At the table, each answer will be a question in the next process. It's important that each Why question is the answer before it, because it will create relation that clear and undeniable.

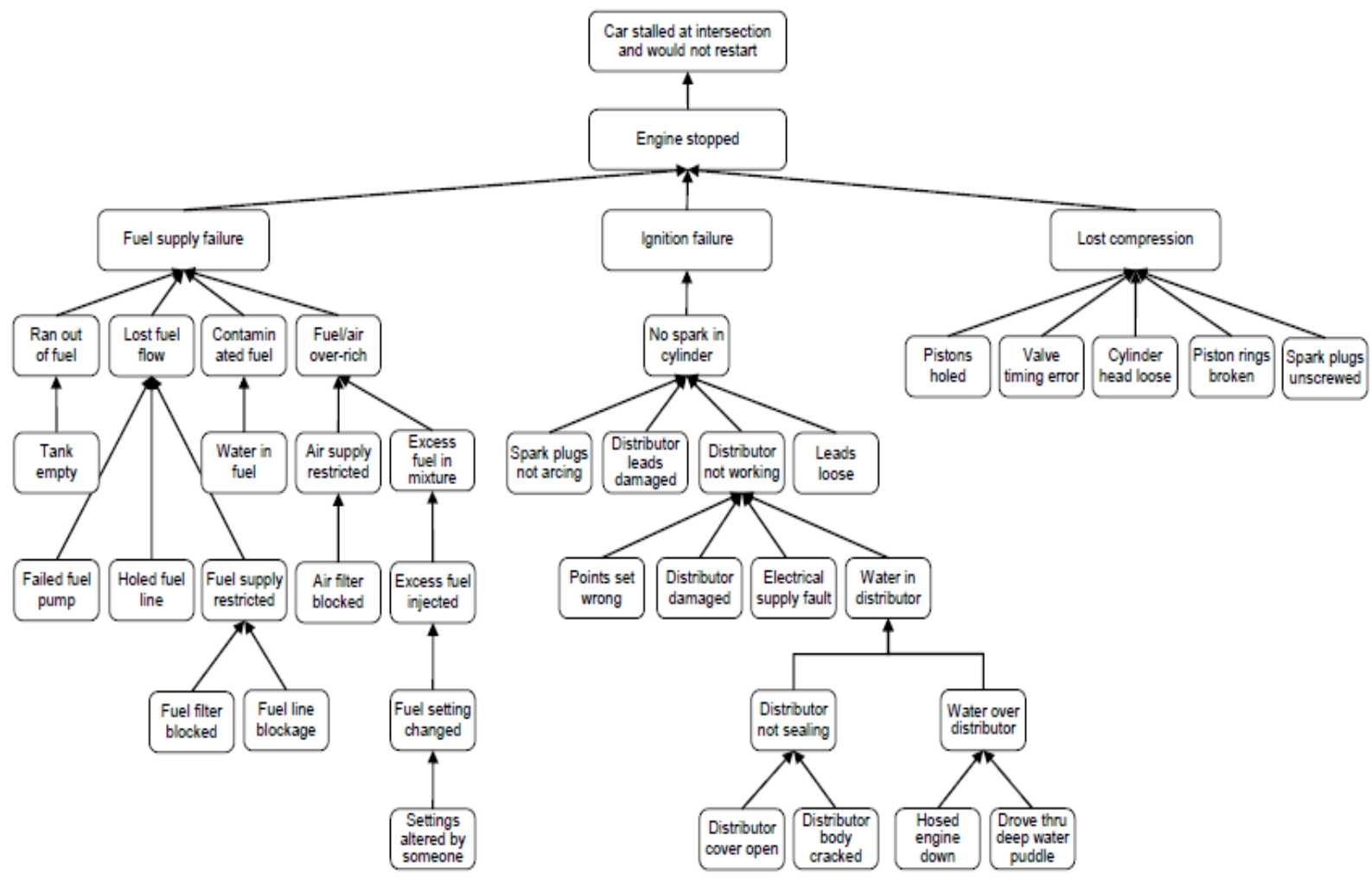

Figure. 1. Example of Why Tree [1]

TABLE 1.

The EXAMPLE OF 5 Whys Question TABLE [1]

\section{5 whys Question Table}

\begin{tabular}{|c|c|c|c|c|}
\hline & & & & \\
\hline Reco & imended Solution: Carry a c & edit card to access money when needed. & & \\
\hline Late & Issues: Putting all the mone & into gambling shows lack of personal contro & and responsibility over mon & \\
\hline No. & Why Questions & Answer & Evidence & Solution \\
\hline 1. & Why did the car stop? & $\begin{array}{l}\text { Because it ran out of gas in a back street } \\
\text { on the way home }\end{array}$ & $\begin{array}{l}\text { Car stopped at side of } \\
\text { road }\end{array}$ & \\
\hline 2. & Why did gas run? & $\begin{array}{l}\text { Because I didn't put any gas into the car on } \\
\text { my way to work this morning. }\end{array}$ & $\begin{array}{l}\text { Fuel gauge showed } \\
\text { empty }\end{array}$ & $\begin{array}{l}\text { Contact work and } \\
\text { get someone to } \\
\text { pick you up }\end{array}$ \\
\hline 3. & $\begin{array}{l}\text { Why didn't you buy gas } \\
\text { this morning? }\end{array}$ & $\begin{array}{l}\text { Because I didn't have any money on me to } \\
\text { buy petrol. }\end{array}$ & $\begin{array}{l}\text { Wallet was empty of } \\
\text { money }\end{array}$ & $\begin{array}{l}\text { Keep a credit } \\
\text { card in the wallet }\end{array}$ \\
\hline 4. & $\begin{array}{l}\text { Why didn't you have any } \\
\text { money? }\end{array}$ & $\begin{array}{l}\text { Because last night I lost it in a poker game } \\
\text { I played with friends at my buddy's house }\end{array}$ & $\begin{array}{l}\text { Poker game is held every } \\
\text { Tuesday night }\end{array}$ & $\begin{array}{l}\text { Stop going to the } \\
\text { game }\end{array}$ \\
\hline 5. & $\begin{array}{l}\text { Why did you lose your } \\
\text { money in last night's } \\
\text { poker game? }\end{array}$ & $\begin{array}{l}\text { Because I am not good at 'bluffing' when } \\
\text { I don't have a good poker hand and the } \\
\text { other players jack-up the bets. }\end{array}$ & $\begin{array}{l}\text { Has lost money in many } \\
\text { other poker games }\end{array}$ & $\begin{array}{l}\text { Go to poker } \\
\text { School and } \\
\text { become better at } \\
\text { 'bluffing, }\end{array}$ \\
\hline
\end{tabular}




\section{II.2. CLASSICIATION SOCIETY RULES}

Based on BKI (Indonesia Clasification Society) Volume III Rules for Machinery Installations Chapter 4 of the Main shafting, which stated that there is a standard material and size for each component [4].

A. Material

In general for the material, the minimum tensile strength for the system shafting (Shaft, Flange couplings, bolts / fitted bolts) is between $400 \mathrm{~N} / \mathrm{mm}^{2}$ to $800 \mathrm{~N}$ / $\mathrm{mm}^{2}$, specifically for fitted bolts connections minimum tensile strength is more than $500 \mathrm{~N} / \mathrm{mm}^{2}$.

However, the value of $\mathrm{Cm}$ were used for the calculation of Rm must be less than:

1. $600 \mathrm{~N} / \mathrm{mm} 2$ for propeller shafts.

2. $760 \mathrm{~N} / \mathrm{mm} 2$ for shafts made of steel except propeller shaft.

3. $800 \mathrm{~N} / \mathrm{mm} 2$ for shafts made of stainless.

B. Dimensioning / Size.

For the minimum diameter shaft size can be determined by the following formula:

$$
\mathrm{Da} \geq \mathrm{d} \geq \mathrm{F} \cdot \mathrm{k} \cdot \sqrt[3]{\frac{\mathrm{Pw}}{\mathrm{n} \cdot\left[1-\left(\frac{\mathrm{di}}{\mathrm{da}}\right)^{4}\right]}} \cdot \mathrm{Cw}
$$

$\mathrm{d}=[\mathrm{mm}]$ minimum required outer shaft diameter

da $=[\mathrm{mm}]$ actual outer shaft diameter

di $=[\mathrm{mm}]$ actual diameter of shaft bore. If the bore

in the shaft is $\leq 0.4$. da, the expression $1-\left(\frac{\mathrm{di}}{\mathrm{da}}\right)^{4}$ may be taken as 1,0

$\mathrm{PW}_{\mathrm{W}}=[\mathrm{kW}]$ rated power of propulsion motor, gear box and bearing losses are not to be subtracted

$\mathrm{N}=[\mathrm{RPM}]$ shaft speed at rated power

$\mathrm{F}=$ factor for type of propulsion installation

a) Propeller shafts

$=100$ for all types of installations

b) Intermediate and thrust shafts

$=95$ for turbine installations, diesel engine installations with hydraulic slip couplings, electric propulsion installations

$=100$ for all other propulsion installations

$\mathrm{Cw}=$ material factor

$$
\frac{560}{\mathrm{Rm}+160}
$$

$\mathrm{Rm}=\left[\mathrm{N} / \mathrm{mm}^{2}\right]$ specified minimum tensile strength of the shaft material (see also B.1)

$\mathrm{k}=$ factor for the type of shaft

\section{a. Intermediate shafts}

$\mathrm{k}=1,0 \quad$ for plain sections of intermediate shafts with integral forged coupling flanges or with shrinkfitted keyless coupling flanges. For shafts with high vibratory torques, the diameter in way of shrink fitted couplings should be slightly increased, e.g. by 1 to $2 \%$.

$\mathrm{k}=1,10$ for intermediate shafts where the coupling flanges are mounted on the ends of the shaft with the aid of keys. At a distance of at least $0,2 \cdot \mathrm{d}$ from the end of the keyway, such shafts can be reduced to a diameter calculated with $\mathrm{k}=1,0$.

$\mathrm{k}=1,10$ for intermediate shafts with radial holes which diameter is not exceeding $0,3 \cdot \mathrm{d}$. Intersections between radial and eccentric axial holes require a special strength consideration. $\mathrm{k}=1,15$ for intermediate shafts designed as multi-splined shafts where $d$ is the outside diameter of the splined shaft. Outside the splined section, the shafts can be reduced to a diameter calculated with $\mathrm{k}$ $=1,0$.

$\mathrm{k}=1,20$ for intermediate shafts with longitudinal slots within the following limitations :

- Slot length up to $0,8 \mathrm{~d}$

- Inner diameter up to $0,8 \mathrm{~d}$

- Slot width e up to $0,1 \mathrm{~d}$

- End rounding at least $0,5 \mathrm{e}$

- 1 slot or 2 slots at $180^{\circ}$ or 3 slots at $120^{\circ}$

Slots beyond these limitations require a special strength consideration.

\section{b) Thrust shafts}

$\mathrm{k}=1,10$ for thrust shafts external to engines near the plain bearings on both sides of the thrust collar, or near the axial bearings where a roller bearing is used.

\section{c) Propeller shafts}

$\mathrm{k}=1,22$ for propeller shafts with flange mounted or keyless taper fitted propellers, applicable to the shaft part between the forward edge of the aftermost shaft bearing and the forward face of the propeller hub or shaft flange, but not less than $2,5 \mathrm{~d}$.

In case of keyless taper fitting, the method of connection has to be approved by BKI.

$\mathrm{k}=1,26$ for propeller shafts in the area specified for $\mathrm{k}=1,22$, if the propeller is keyed to the tapered propeller shaft.

$\mathrm{k}=1,40$ for propeller shafts in the area specified for $\mathrm{k}=1,22$, if the shaft inside the stern tube is lubricated with grease.

$\mathrm{k}=1,15$ for propeller shafts between forward end of aft most bearing and forward end of fore stern tube seal. The portion of the propeller shaft located forward of the stern tube seal can gradually be reduced to the size of the intermediate shaft.

\section{II.2. FINITE ELEMENT METHOD (FEM)}

The finite element method (FEM) is a numerical method for solving problems of engineering and mathematical physics. It is also referred to as finite element analysis (FEA) [2][3]. Typical problem areas of interest include structural analysis, heat transfer, fluid flow, mass transport, and electromagnetic potential. The analytical solution of these problems generally require the solution to boundary value problems for partial differential equations. The finite element method formulation of the problem results in a system of algebraic equations. The method yields approximate values of the unknowns at discrete number of points over the domain. To solve the problem, it subdivides a large problem into smaller, simpler parts that are called finite elements. The simple equations that model these finite elements are then assembled into a larger system of equations that models the entire problem. FEM then uses variational methods from the calculus of variations to approximate a solution by 
minimizing an associated error function. In Figure 2 is the example of FEM modelling

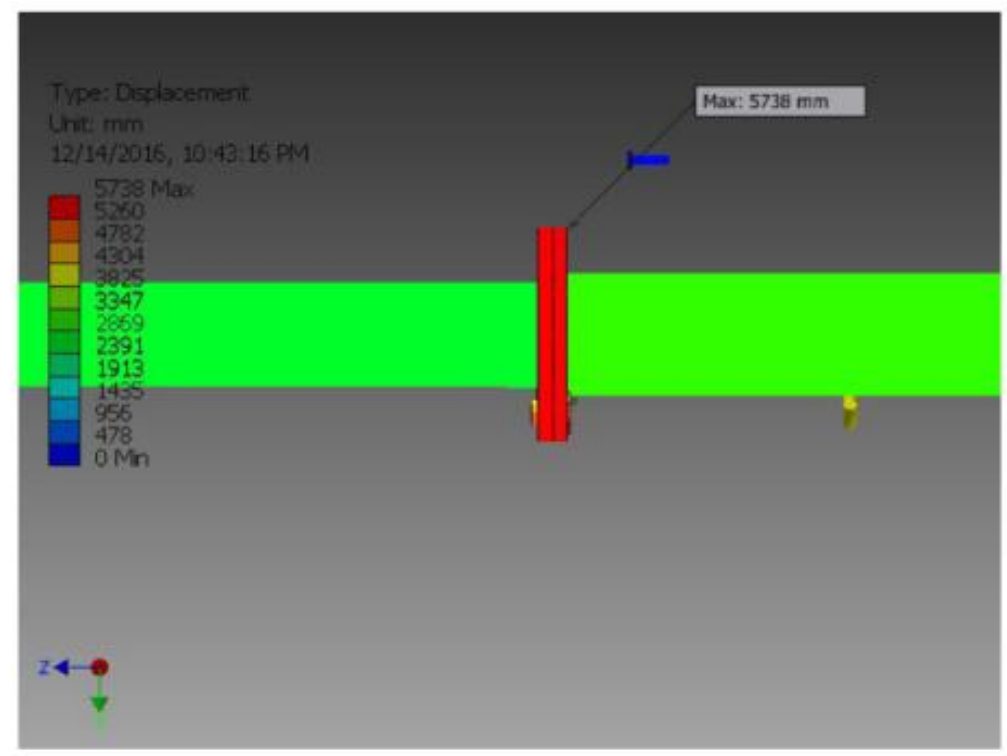

Safety Factor

Figure. 2. Example of FEM modelling.

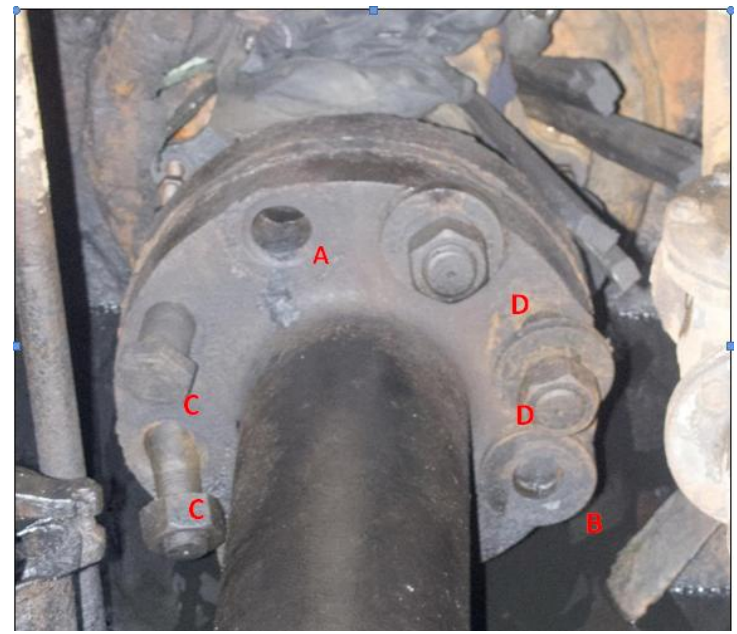

Figure. 3. Flange Condition After The Accidents

\section{RESULT AND DISCUSSION}

\section{III.1. IDENTIFICATION AND ANALYSIS.}

Shafting system as shown in Figure 3 is a system that has the function to deliver trust power from the main engine (prime mover) to the propeller, therefore the vessel can get a thrust in accordance with the expected. In this case, KM. Nusantara Akbar shafting use sea water lubrication system.

To facilitate the problem identification of shafting system KM. Nusantara Akbar will be divided into several parts according to its main components, such as:
1. Intermediate shaft
5. Packing
2. Bearing
3. Clutch
6. Propeller shaft

4. Stern tube
While the field data obtained from the KNKT after the accidents is as shown like on Figure 3.

1. 1 piece coupling bolts are not in place $(\mathrm{A})$.

2. 1 piece of broken coupling bolts (B)

3. 2 pieces almost detached, the possibility is breaking up the middle

4. 2 bolts still attached but there is an additional ring, it should not be.

5. 2 pieces bolts that are at the bottom is not visible in this image.

6. Seeing fastening bolt on the clutch shaft, it is likely not a fitted bolt.

7. When the intermediate shaft is rotating, intermediate shaft bearings going to sway. To reduce the sway then mounted a tackle block as in Figure 4 (in this picture chain fastened to the foundation bearing tackle) 


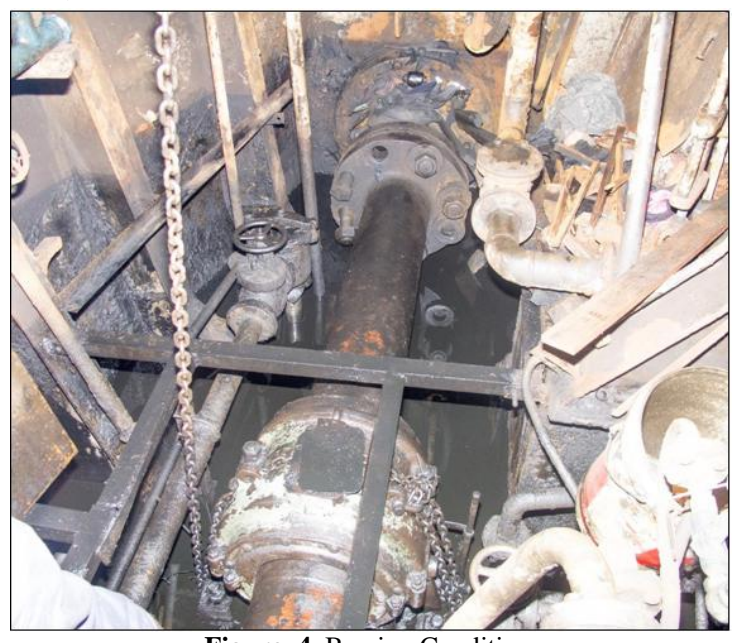

Figure. 4. Bearing Condition

\section{(1). CERTIFICATES AND VESSEL DOCUMENTS}

Certificates and vessel documents are evidences that indicating the seaworthiness of vessel. These documents also show that the vessel was in good condition according to the rules applicable on the classification (BKI) and Statutory Regulation.

\section{(2). INCIDENT REPORTS.}

Reports on the incidents is a report on an event or an accident which was written by someone in order to provide a detailed explanation in the form of a letter or writing, accompanied by evidence that has been found.

The event sequence of KM. Nusantara Akbar accidents is as follows:

1. The water enters into the engine room through the propeller shaft stern tube.

2. Blockage a used wear pack to reduce the flow rate of water into the engine room.

3. Binding of retaining reamers packing but it was fail.

4. The seawater soaking up the engine room until disturb on the rotating main engine flywheel.

5. Additional blockage is added by using the board pieces at the stern tube propeller shaft in the engine room.

From the data identification associated with the incident report contained findings that:

1. The master did not know that one of his crew was panic when flooding happened and immediately took the emergency pump in fresh water tank which then lead to death.

2. When the flooding happened crew only protect themselves by not appropriate equipment such as wear pack and pieces of wood.

\section{(3). DOCKING REPORTS}

Docking report is a job report when the vessel was being repaired on the dock from contracts repair; vessel goes up the dock till the vessel goes down from dock.

From the identification data related with docking report, found that:

1. The broken flange bolt was not replaced but reconditioned. (Welded)

2. There is no special treatment when carried out repairs on the propeller.
3. The shalft alignment was not conducted but improved by setting flax to shrink deflection.

\section{(4). CREW CERTIFICATES}

Crew certificates are evidences, which describing crew profiles, level of expertise and skills possessed the crew. After identification the crew certificates are finding that some of the crew certificate was expired.

\section{(5). OTHER DOCUMENTS RELATED TO VESSEL.}

From the identification of relevant data supporting documents related to vessel are finding that the condition of the vessel is dirty and there are mice.

\section{III.2. CAUSE ANALYSIS}

(1). Technical Factors

(a) 5 Whys

After doing the analysis and identification of the data that have been obtained, the next step is to analyze the causes of failure of the propeller shaft deflection.

The first step is to choose the top event, according to the guide, the top event is chosen from events or incidents that have occurred. Engine room flooding incident at KM Nusantara Akbar is chosen as the top event.

In the second step, the the question of why are carried out. This question covers of technical and non-technical factors. Then the answers for the first why question there is flooding in the engine room are as follows:

1.1. Unpreparedness to face the damage / failure of the system.

1.2. Damage / failure of internal systems (shafting system).

In the third step is giving the question why in every answer in 1.1 and 1.2 above. The answer of each question is:

1.1. Why happened the unpreparedness to face the damage /failure of the system?

1.1.1. Because crew is not responsive to face the failure of the system.

1.1.2. Because the equipment was insufficient to handle failure

1.1.3. Because working environments conditions are dirty and not comfortable. 
1.2. Why were there failures of internal systems (shafting system)?

1.2.1. The shaft deflection (Deflection)

1.2.2. Failure on Packing and Seal (could not resist the rate of water)

In the fourth step is giving why question to the third step answer (1.1.1). The answer of each question is:

1.1.1. Why do the crews not responsive to face the failure of the system?

1.1.1.1. Because there were miscommunication between crew

1.1.1.2. Because the crew was less competent

1.1.1.3. Because the physical and psychological conditions of crew was unfavorable

1.1.3. Why the working environment was dirty?

1.1.3.1. Because the crew was slovenly

1.1.3.2. Because operator ignored the vessel condition

1.2.1. Why the shaft deflection

1.2.1.1. Because related components less support (Flange and Bearing)

1.2.1.2. Because the shaft operation was beyond the expexted load.

1.2.2. Why the packing could not resist the water rate?

1.2.2.1. Because Encouraged / disturbed by shaft deflection

1.2.2. Because an error in the installation.
In the fifth step is giving why question to the fourth step answer. The answer of each question is:

1.1.1.2. Why was the crew standard of competence less?

1.1.1.2.1. Because the crew did not renew the certificate of member vessel.

1.1.1.2.1. Because there is no facility from vessel operators

1.2.1.1. Why the associated components was not supported (flange and bearing)

1.2.1.1.1. Because the maintenance of flange and bearing were not in accordance with the standards

1.2.1.1.2. Because the components were less well 1.2.1.2. Why was the operation shaft more than the expected load?

1.2.1.2.1. Because the load was too heavy

In the sixth step is giving why question to the fifth step answer. The answer of each question is:

1.2.1.1.1. Why were the maintenance of flange and bearing not compliant?

1.2.1.1.1.1. Because when the bolts was broken, it was not replaced with new one but reconditioned (welded) the bolts.

1.2.1.1.1.2. Because the addition of flax was on the bearings to handle deflection shaft.

Then on the Figure 5 below is the result of why tree which has been described from the above process: 


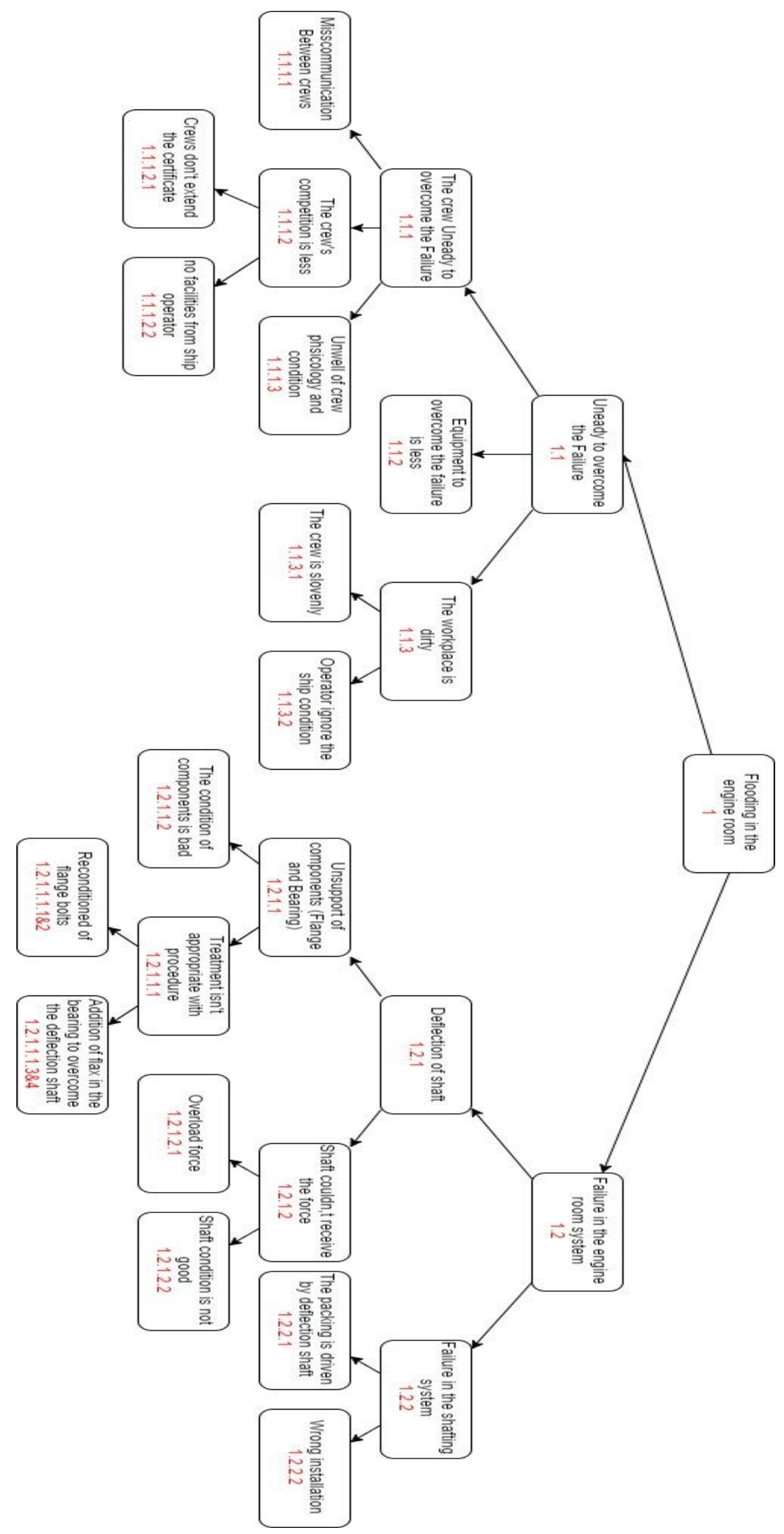

Figure. 5. Why Tree of flooding in the engine room of KM. Nusantara Akbar case

After the analysis of the why tree is complete then the matrixes inserted into the 5 whys question table as in table 2. The events are entered into the table 5 whys question are events which have been reinforced by the evidence above, thereore, the right solutions are obtained. 
TABLE 2 .

5 WHYS QUESTION TABLE FOR TECHNICAL FActors

\begin{tabular}{|c|c|c|c|c|}
\hline \multicolumn{5}{|c|}{5 Whys Question Table } \\
\hline \multicolumn{5}{|c|}{ Problem Statement: Flooding in the engine room } \\
\hline \multicolumn{5}{|c|}{$\begin{array}{l}\text { Recommended Solution: Perform maintenance according to the procedure: replacing the flange bolts if damaged and then adjust } \\
\text { the straightening shaft bearing depend on the shaft }\end{array}$} \\
\hline \multicolumn{5}{|c|}{ Latent Issues: Not treated maintenance in accordance with the procedure when in dock } \\
\hline No. & Why Questions & Answer & Evidence & Solution \\
\hline 1. & $\begin{array}{l}\text { Why was there flood } \\
\text { in the engine room of } \\
\text { KM. Nusantara Akbar } \\
\text { ? }\end{array}$ & $\begin{array}{l}\text { Because damage / failure } \\
\text { of internal systems } \\
\text { (shafting system).. (1.2) }\end{array}$ & $\begin{array}{l}\text { Flooding in the engine room } \\
\text { of KM. Nusantara Akbar }\end{array}$ & \\
\hline 2. & $\begin{array}{lr}\text { Why was there } \\
\text { damage / failure of } \\
\text { internal } & \text { systems } \\
\text { (shafting system)?(1) }\end{array}$ & $\begin{array}{l}\text { Because there was failure } \\
\text { on shafting system } \\
\text { (Deflection) }(1.2 .1)\end{array}$ & $\begin{array}{l}\text { Packing driven by shaft } \\
\text { deflection so that packing was } \\
\text { not able to withstand the rate } \\
\text { of water }\end{array}$ & $\begin{array}{l}\text { Prepare the spare parts/tools to } \\
\text { face the failure. }\end{array}$ \\
\hline 3. & $\begin{array}{l}\text { Why was there a } \\
\text { failure in the shafting } \\
\text { system(deflection)? } \\
(1.2 .1)\end{array}$ & $\begin{array}{lr}\text { Because } & \text { related } \\
\text { components less } & \text { support } \\
\text { (Flange } & \text { and } \\
\text { Bearing)(1.2.1.1) } & \\
\end{array}$ & $\begin{array}{l}\text { Flange bolts were broken and } \\
\text { bearing is sway }\end{array}$ & $\begin{array}{l}\text { Regularly check the shaft } \\
\text { deflection and maintain the } \\
\text { permitted limit }\end{array}$ \\
\hline 4. & $\begin{array}{l}\text { Why the associated } \\
\text { components was not } \\
\text { supported (flange and } \\
\text { bearing)?(1.2.1.1) }\end{array}$ & $\begin{array}{l}\text { Because the maintenance } \\
\text { of flange and bearing } \\
\text { were not in accordance } \\
\text { with the standards. } \\
(1.2 .1 .1 .1)\end{array}$ & $\begin{array}{l}\text { Flange bolts were broken and } \\
\text { bearing was sway }\end{array}$ & $\begin{array}{l}\text { Check the size and strength of } \\
\text { bearing and flange }\end{array}$ \\
\hline \multirow[t]{2}{*}{5.} & $\begin{array}{l}\text { Why the maintenance } \\
\text { of flange and bearing } \\
\text { were not compliant? } \\
(1.2 .1 .1 .1)\end{array}$ & $\begin{array}{l}\text { Because when the bolts is } \\
\text { broken not replaced but } \\
\text { reconditioned.(welded) } \\
(1.2 .1 .1 .1 .1)\end{array}$ & Welding flange bolts & $\begin{array}{l}\text { perform } \\
\text { maintenance } \\
\text { replacing the flange bolts if } \\
\text { damaged and adjust the shaft }\end{array}$ \\
\hline & & $\begin{array}{l}\text { Because the addition of } \\
\text { flax on the bearings to } \\
\text { handle deflection shaft } \\
(1.2 .1 .1 .1 .2)\end{array}$ & $\begin{array}{l}\text { The addition of flax on the } \\
\text { bearings }\end{array}$ & then straightening shaft bearing \\
\hline
\end{tabular}

(b). Calculate the minimum diameter of shaft according to the BKI rules

From the data, known,

$\mathrm{P} \mathrm{m} / \mathrm{e}$

: $3850 \mathrm{~kW}$

Material : Stainless Steel

$\mathrm{Rm} \quad: 480 \mathrm{~N} / \mathrm{mm}^{2}$

Intermediate shaft :

$\begin{array}{ll}\mathrm{L} & : 4000 \mathrm{~mm} \\ \mathrm{D} & : 275 \mathrm{~mm}\end{array}$

Propeller/Tail Shaft

$\begin{array}{ll}\mathrm{L} & : 3200 \mathrm{~mm} \\ \mathrm{D} & : 320 \mathrm{~mm}\end{array}$

Intermediate shaft Calculation

$\mathrm{Da} \geq \mathrm{d} \geq \mathrm{F} \cdot \mathrm{k} \cdot \sqrt[3]{\frac{\mathrm{Pw}}{\mathrm{n} \cdot\left[1-\left(\frac{\mathrm{di}}{\mathrm{da}}\right)^{4}\right]}} \cdot \mathrm{Cw}$
$275 \geq \mathrm{d} \geq 100.1 \cdot \sqrt[3]{\frac{3860}{\mathrm{n} \cdot\left[1-\left(\frac{\mathrm{di}}{\mathrm{da}}\right)^{4}\right]}} \cdot \frac{560}{480+160}$

$275 \mathrm{~mm} \geq \mathrm{d}(\mathrm{mm}) \geq 263 \mathrm{~mm}$

The diameter of Intermediate shaft was fulfilled of BKI rules standard.

Propeller shaft Calculation

$\mathrm{Da} \geq \mathrm{d} \geq \mathrm{F} . \mathrm{k} \cdot \sqrt[3]{\frac{\mathrm{Pw}}{\mathrm{n} \cdot\left[1-\left(\frac{\mathrm{di}}{\mathrm{da}}\right)^{4}\right]}} \cdot \mathrm{Cw}$
$320 \geq \mathrm{d} \geq 100.1,15 \cdot \sqrt[3]{\frac{3850}{\mathrm{n} \cdot\left[1-\left(\frac{\mathrm{di}}{\mathrm{da}}\right)^{4}\right]}} \cdot \frac{560}{480+160}$

$320 \mathrm{~mm} \geq \mathrm{d}(\mathrm{mm}) \geq 302,45 \mathrm{~mm}$

The diameter of propeller shaft was fulfilled of BKI rules standard

(c). Finite Element Method/Finite Element Analysis

At this step, using FEM modeling to confirm the findings of the KNKT field data Related broken bolts on the flange as in Figure 3. The working force on the shaft is on Figure 6.

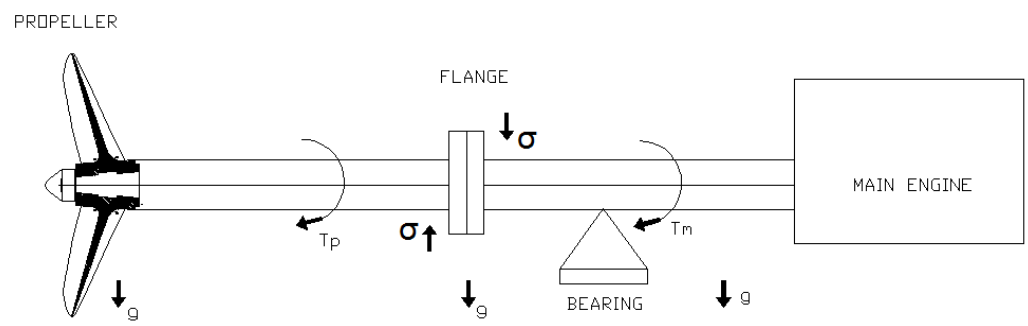

Figure. 6. Free Body Diagram 
Explanation :

O: shear force from the main engine and propeller torque to the flange bolts

Tm: Main Engine Torque

Tp: Propeller Torque

$\mathrm{g}$ : gravity

The force known as :

O : 1,951 Mpa

Tm : $19827.4 \mathrm{Nm}$

$\mathrm{Tp}: 19430.86 \mathrm{Nm}$

$\mathrm{F}: 9434.531 \mathrm{~N}$

Abolt $: 4.835 \mathrm{~cm}^{2}$

With FEM calculation obtained that the normal shear stress is :

$$
T=\frac{\mathrm{F}}{\mathrm{A}}
$$

$$
\begin{gathered}
T=\frac{9434.531}{4.835} \\
=1.951 \mathrm{MPa}
\end{gathered}
$$

Then with 7 bolts the shear stress is : $\mathrm{F}=9434.531 \times(8 / 7)=10782.31 \mathrm{~N}$

$$
\begin{gathered}
T=\frac{\mathrm{F}}{\mathrm{A}} \\
T=\frac{10782.31}{4.835} \\
=2.230 \mathrm{MPa}
\end{gathered}
$$

(2). Non-Technical Factors Analysis

The first step is to create Why tree to analyze the cause before use 5 whys Table. Why tree used is why tree

\begin{tabular}{|c|c|c|c|c|}
\hline \multicolumn{5}{|c|}{5 Whys Question Table } \\
\hline \multicolumn{5}{|c|}{ Problem Statement: Flooding in the engine room } \\
\hline \multicolumn{5}{|c|}{ Recommended Solution: prepare the spare parts/tolls related to overcome the failure, increase communication system } \\
\hline \multicolumn{5}{|c|}{ Latent Issues: Not preparing spare parts / equipment safety to prevent shafting system failures. } \\
\hline No. & Why Questions & Answer & Evidence & Solution \\
\hline 1. & $\begin{array}{l}\text { Why was there flooding in } \\
\text { the engine room of KM. } \\
\text { Nusantara Akbar? }\end{array}$ & $\begin{array}{l}\text { Because unpreparedness } \\
\text { to face the damage / } \\
\text { failure of the system.(1.1) }\end{array}$ & $\begin{array}{l}\text { Flooding in the engine room } \\
\text { of KM. Nusantara Akbar }\end{array}$ & \\
\hline \multirow[t]{3}{*}{2.} & $\begin{array}{l}\text { Why did happen the } \\
\text { unpreparedness to face the } \\
\text { damage /failure of the } \\
\text { system?(1.1) }\end{array}$ & $\begin{array}{l}\text { Because crew was not } \\
\text { responsive to face the } \\
\text { failure of the system } \\
(1.1 .1)\end{array}$ & $\begin{array}{l}\text { Prevention of leaks using } \\
\text { makeshift tools. }\end{array}$ & $\begin{array}{l}\text { prepare the spare parts/tolls related } \\
\text { to overcome the failure }\end{array}$ \\
\hline & & $\begin{array}{l}\text { Because the equipment } \\
\text { was insufficient to handle } \\
\text { failure. (1.1.2.) }\end{array}$ & & \\
\hline & & $\begin{array}{l}\text { Because the working } \\
\text { environment was dirty } \\
(1.1 .3)\end{array}$ & & \\
\hline \multirow[t]{5}{*}{3.} & $\begin{array}{l}\text { Why were the crews not } \\
\text { responsive to face the } \\
\text { failure of } \\
\text { system?(1.1.1) }\end{array}$ & $\begin{array}{l}\text { Because the lack of crew } \\
\text { competency } \\
\text { standards.(1.1.1.2) }\end{array}$ & $\begin{array}{l}\text { Captain did not know the } \\
\text { crew was killed because of } \\
\text { panic. }\end{array}$ & $\begin{array}{l}\text { Train communication and team } \\
\text { work }\end{array}$ \\
\hline & & $\begin{array}{l}\text { Miscommunication } \\
\text { between crew (1.1.1.1) }\end{array}$ & & \\
\hline & $\begin{array}{l}\text { Why was the equipment to } \\
\text { deal the failure is } \\
\text { insufficient? (3.2) }\end{array}$ & $\begin{array}{l}\text { Because of the lack of } \\
\text { procurement from the } \\
\text { operator. (3.2.A) }\end{array}$ & $\begin{array}{l}\text { Crew handle flood using } \\
\text { boards and clothes wear pack }\end{array}$ & $\begin{array}{l}\text { Ask the operator to conduct the } \\
\text { procurement of spare parts }\end{array}$ \\
\hline & $\begin{array}{l}\text { Why was the working } \\
\text { environment dirty? }(1.1 .3)\end{array}$ & $\begin{array}{l}\text { Because the crew was } \\
\text { slovenly }(1.1 .3 .1)\end{array}$ & $\begin{array}{l}\text { The work space was dirty and } \\
\text { there were mice }\end{array}$ & $\begin{array}{l}\text { Clean the work space after and } \\
\text { before shift changes }\end{array}$ \\
\hline & & $\begin{array}{l}\text { Because operator ignored } \\
\text { the vessel condition } \\
(1.1 .3 .2)\end{array}$ & $\begin{array}{l}\text { Get warning from the health } \\
\text { department }\end{array}$ & $\begin{array}{l}\text { Well-prepared coordination and } \\
\text { teamwork before sailing in the sea. }\end{array}$ \\
\hline 4 & $\begin{array}{l}\text { Why was the crew } \\
\text { standard of competence } \\
\text { less? (3.3.A) }\end{array}$ & $\begin{array}{l}\text { Because the crew did not } \\
\text { renew the certificate of } \\
\text { member vessel. (3.3.A) }\end{array}$ & $\begin{array}{l}\text { The crews certificates were } \\
\text { expired. }\end{array}$ & $\begin{array}{l}\text { Make clear rules on the cleanliness } \\
\text { of the vessel. }\end{array}$ \\
\hline
\end{tabular}
similar to that used for technical factors analysis. Then for the matrix that has been reinforced by the evidence to be inserted into the 5 whys table in Table 3 below.

TABLE 3.

5 WHYS TABLE FOR NON-TECHNICAL FACTORS

\section{CONCLUSION}

Based on the analysis that had been done, through it can be concluded that the flooding of KM. Nusantara Akbar was casused as follows:

Technical factors:

1. The diameter size of KM. Nusantara Akbar is 275 $\mathrm{mm}$ for intermediate shaft and $320 \mathrm{~mm}$ for propeller shaft, while the minimum diameter of the calculation according to the BKI rules is $263 \mathrm{~mm}$ for intermediate shaft and $302.45 \mathrm{~mm}$ for propeller shaft, which means it complies with the minimum standards of BKI.

2. From the KNKT's data, some flange bolts were broken and loose, from the FEM modeling obtained bolt broken because the working force was beyond the normal load. 
3. Welding of flange bolts that have been broken shall not be carried out because it will change the character of the material that has received heat and the addition of different materials.

4. The addition of flax in the bearing to adjust the deflection shaft should not be carred because the point of deflection will creep at another point.

Non-Technical Factors:

1. The using a piece of board and crew wear pack were not appropriate tool to blockage the the Engine Room Flooding, because they will damage related components and endanger the safety of the crew.

2. It is found that miscommunication happened between crews, because miscommunication will lead to a decreased level of success in a team work.

3. Working room was very dirty, interfereing with the work of the crew.

\section{REFERENCES}

[1] M. Sondalini, How to Use 5 Whys for Root Cause Analysis, 1st ed., lifetime-reliability.com.

[2] R. Praharaj, "Failure Prediction of Propeller Shaft Prototype Using Finite Element Analysis," Mumbai.

[3] P. Assi, "FE Analysis of Hollow Propeller Shaft Using Steel and Composite Material then Compares it," Ahmedabad.

[4] B. K. Indonesia, Volume III Rules for Machinery Installations, 1st ed., BKI, 2015. 